\title{
BUILDING INTEGRATED PHOTOVOLTAIC SOLUTIONS IN ARID CLIMATES: EXPERIMENTAL ANALYSIS OF COPPER INDIUM GALLIUM SELENIDE AND CRYSTALLINE SILICON MODULES INTEGRATED AS VENTILATED FAÇADES
}

\author{
EDWIN RODRIGUEZ-UBINAS, NOURA ALHAMMADI, MOHAMED ALANTALI \& SARAH ALZAROUNI \\ DEWA R\&D Center, Dubai Electricity and Water Authority, UAE
}

\begin{abstract}
This paper presents a test and validation research on the energy performance of photovoltaic solutions integrated as opaque, ventilated façades in the harsh desert climate of Dubai, UAE. We have assessed the performance of copper indium gallium selenide (CIGS) and monocrystalline silicon (c-Si) modules in the three most suitable orientations for Dubai's buildings (south, east, and west), over one full year. Additionally, we investigated the effect of modules' temperature on the energy yield. The normalized energy yield of c-Si modules was continuously higher than the CIGS modules, across all orientations, with an average annual difference of $13.6 \%$. Throughout the whole period, the south-oriented modules produced more energy than those in the east and west. During the period from October to February, they produced up to $48.5 \%$ more than the other orientations. The east and west façades, on the other hand, produced up to $40.9 \%$ more energy than the south in the period from April to August. Furthermore, although the annual irradiance on the west was only $1.7 \%$ lower than the east, the annual production of the west modules was more than $12 \%$ less. These modules start to receive direct solar irradiation in the afternoon when ambient temperatures reach their highest values, and after they accumulated heat during the morning.
\end{abstract}

Keywords: crystalline silicon, c-Si, CIGS, ventilated façade, building integrated photovoltaics, BIPV, solar energy, façade, rainscreen.

\section{INTRODUCTION}

Building energy consumption constitutes about a third of the total primary energy demand in the UAE. In Dubai, buildings are responsible for more than $50 \%$ of total electricity consumption and up to $70 \%$ of the peak load during the summer months. As a response to that reality, initiatives that aim in reducing buildings' energy use and transforming them into prosumers are essential pillars of the Dubai Demand Side Management (DSM) program [1]. In 2015, the Dubai Electricity and Water Authority, as part of its contribution to the DSM strategy, defined its Distributed Renewable Resources Generation program and launched the Shams Dubai initiative to connect solar energy to buildings. The initial focus of Shams Dubai was on building applied photovoltaics (BAPV) - mostly rooftop installations. Currently, its regulations are under revision to facilitate the connection of building integrated photovoltaics (BIPV) solutions.

BIPV are multifunctional elements that, in addition to electricity generation, have further purposes including replacing conventional building materials. They can be part of the roofs, opaque walls, glazing, and solar control elements [2]. In addition to their multifunctional and aesthetic contribution, BIPV solutions enable covering larger surfaces of the buildings comparing to BAPV. This fact is especially relevant in cities like Dubai with many high-rise buildings, in which the roof area is not enough to produce the required energy to achieve the nearly zero energy level [3]. 
In hot climates, cooling systems are responsible for most of the energy consumption in buildings. The most effective way to reduce the cooling loads is the adequate selection of the buildings' envelope. In the last years, many researchers have shown interest in opaque ventilated façades, also known as rainscreen façades, for their capability to reduce the cooling needs in buildings [4]. In these façades, the thermal envelope is protected from the solar irradiation by an exterior layer, separated by a ventilated cavity. The use of BIPV as the outer surface permits to reduce the building cooling needs and produce electricity. Additionally, the BIPV modules can be rear ventilated, which reduces the performance losses due to higher module temperatures. These façades can be used on residential and commercial buildings, and in both new and existing structures.

Ventilation is an essential component in BIPV, especially in countries with hot climate conditions. A retrofit case study in Madrid [5] observed a nominal PV temperature difference of $12^{\circ} \mathrm{C}$ between naturally ventilated and non-ventilated crystalline silicon (c-Si) BIPV façades, which has resulted in an improvement of $2.5 \%$ of its efficiency. An experimentalnumerical study in Azmir found that the assessed the performance of a c-Si PV façade showed that natural ventilation increased the electricity output by about $2 \%$ yearly [6]. Researchers in Greece found that an open-ended air gap of $10 \mathrm{~cm}$ permits an adequate natural airflow for BIPV ventilated façades, maintaining the PV cladding in a temperature range that reduces performance losses. These researchers observed that wider air gaps further reduce the PV peak temperature but just slightly. Therefore, they concluded that $10 \mathrm{~cm}$ is the optimum width for this type of façade [7], [8]. Furthermore, a simulation study shows that open-joint ventilated façades are an optimum solution for BIPV and can help to obtain significant energy savings in climates with hot summers and mild winters [9].

Crystalline silicon is a highly reliable technology for almost all types of PV applications. This technology has a market penetration of about $90 \%$ and will remain as a relevant technology for the upcoming decades [10]. While crystalline silicon modules are known for their superior performance, thin-film modules, and especially CIGS, are highly suitable for façade applications due to their excellent performance under low-light conditions, flexibility, lightweight, and low temperature coefficients that lead to less susceptibility to heat-related performance losses [3], [11]. In a solar energy review for the UAE, the authors reported that organic solar cells perform better than other technologies under the UAE climate; however, their rapid degradation remains their main drawback [12].

To determine the performance of different PV technologies in arid climates, researchers from the DEWA R\&D Center carried out a study to assess six types of PV modules in three different tilt angles, $5^{\circ}, 25^{\circ}$, and $90^{\circ}$ [5]. The bifacial monocrystalline modules showed the highest normalized yield in comparison with conventional poly-Si and mono-Si modules, glass-glass poly-Si, and CIGS and CdTe thin-film modules. The most significant causes of power losses were the high temperatures and soiling. Additionally, even though the thin-film modules have the lowest temperature coefficients, the soiling effect has significantly reduced their daily yields due to their high bandgap. The $5^{\circ}$ and $25^{\circ}$ tilted modules experienced significant soiling losses in comparison with the negligible losses at $90^{\circ}$. That is an advantage for the integration of PV in the façades of the buildings in the Arabian Peninsula. In a comparative modeling study for Abu Dhabi [13] on the impact of 10 tilt angles on the energy yield of 5 different PV modules, the authors found that optimum angles were between $20^{\circ}$ to $24^{\circ}$. They also found that yields of the modules at $0^{\circ}$ and $90^{\circ}$ were $7 \%$ and $45 \%$ less than the optimum ones [14]. The same study has concluded that the energy yields of the CIGS and CdTe thin-film modules were around 13\% higher than the crystalline silicon modules (pc-Si and $\mathrm{mc}-\mathrm{Si}$ ) due to their low-temperature coefficients. 
In Germany, PV modules facing east and west could be economically viable, considering the self-consumption rate and internal rate of return (IRR) as an alternative to the optimum south orientation [15]. In the UK, top-facing OPV modules perform better than the modules in the façades. However, they also noted that the west-facing BIPV contributed significantly to meeting the peak-period energy demand [16].

More studies on BIPV in arid climates are necessary to determine the PV performance after their integration in buildings, the effect of high temperatures on the modules' efficiency and lifetime, the impact of BIPV on buildings' cooling loads, and the optimization of the PV modules configuration and technology [17]. To address these, we carried out a comparative experimental research of BIPV ventilated façades in Dubai's climate. Our study assesses the energy behavior of CIGS and c-Si BIPV technologies integrated as wall cladding and the influence of the high temperature and orientation on their performance.

\section{METHODOLOGY}

To carry out our experimental research on BIPV ventilated façades in Dubai, we utilized the CUBE - one of the outdoor test facilities of the Dubai Electricity and Water Authority R\&D Center (Fig. 1). The DEWA R\&D Center is part of the Mohammed Bin Rashid Al Maktoum Solar Park, located in Saih Al Dahal desert, Dubai, the UAE (23.4241 $\left.{ }^{\circ} \mathrm{N}, 53.8478^{\circ} \mathrm{E}\right)$. The PV modules in the CUBE are part of an open-joint ventilated façade. The CUBE envelope contains a $12 \mathrm{~cm}$ insulation layer and an $8.3 \mathrm{~cm}$ ventilation gap between the modules and the insulation layer as per Fig. 2. Vertical and horizontal joints $(1.2 \mathrm{~cm})$ separate the PV modules.

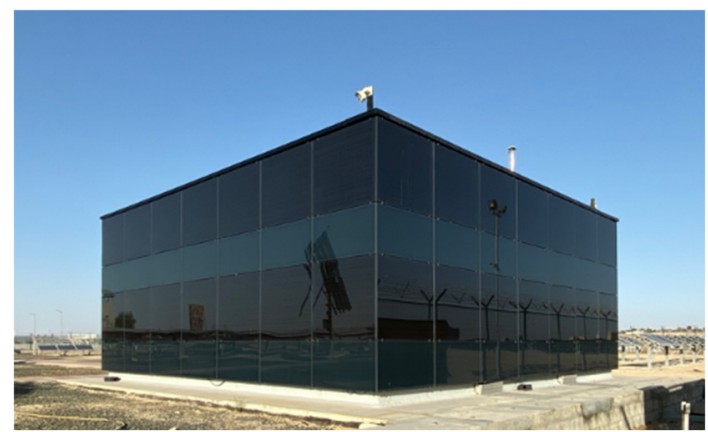

Figure 1: The CUBE BIPV test facility at DEWA R\&D center. (Source: Photo by authors.)

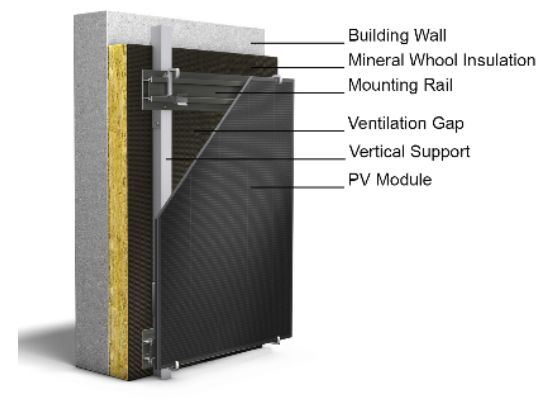

Figure 2: Components of the BIPV façade. (Source: Lithodecor.)

The CUBE integrates PV modules as a ventilated façade on three orientations (south, east, and west). Each one of its façades has fourteen 1.2 x $0.6 \mathrm{~m}$ Copper Indium Gallium Selenide (CIGS) cladding modules and fourteen $1.2 \times 1 \mathrm{~m}$ monocrystalline silicon (c-Si) cladding modules. These technologies were selected because they are the two most used technologies in BIPV products, and are suitable for integration in ventilated façades. These modules differ in efficiency, rated power, and temperature coefficient. The rated power and temperature coefficients of the CIGS and c-Si are $90 \mathrm{~W},-0.36 \% /{ }^{\circ} \mathrm{C}$, and $185 \mathrm{~W},-0.43 \% /{ }^{\circ} \mathrm{C}$, respectively.

We monitored the modules continuously using an I-V tracer. Furthermore, we connected each module to an electronic load that performs the maximum power point tracking (MPPT) and logs its electrical parameters every 30 seconds. 
In addition to the energy yield measurements, we used three pyranometers to measure the solar irradiation at a $90^{\circ}$ plane in the three façade orientations (east, west, and south). Also, we installed flat film Pt100 thermal sensors at the back of each module to monitor its temperature. We used the ambient temperature, relative humidity, wind direction and velocity, and other environmental data from the DEWA R\&D Center weather station.

The study's duration was 1 year, which covers the period from March 2018 to February 2019. We used the measured power to calculate the daily energy yield of both technologies, which we normalized to the module area before comparing the performance. Additionally, we analyzed the temperatures of the modules at all orientations across the study period to verify the technologies' thermal performance and the impact of Dubai's typical high temperatures on the modules efficiency.

\section{RESULTS AND DISCUSSION}

During the year of experimentation, the south façade received more solar energy than the other façades, as we show in Fig. 3(a) and 3(b). The south façade received 1,452 kWh/m², and the east and west façades received 1,255 and $1,234 \mathrm{kWh} / \mathrm{m}^{2}$, respectively. From October to February, the south façade collected the highest amount of irradiation due to the low solar altitude during the central hours of the day. In December, the south façade received more than the double of the irradiation received by the east and west façades. However, in the months in which the solar altitude is high during the central hours of the day - April to August - the collected irradiation in the south was the lowest. Conversely, the east and west façades received the highest amount of irradiation in this period. In June, the incident solar energy in both the east and west façades were more than $90 \%$ higher than the south façade. During the periods close to the equinoxes - months of March and September - the irradiation ranges from the south, east, and west is similar. In September, the difference between the monthly mean daily of the south and east façade is just $2.4 \%$.
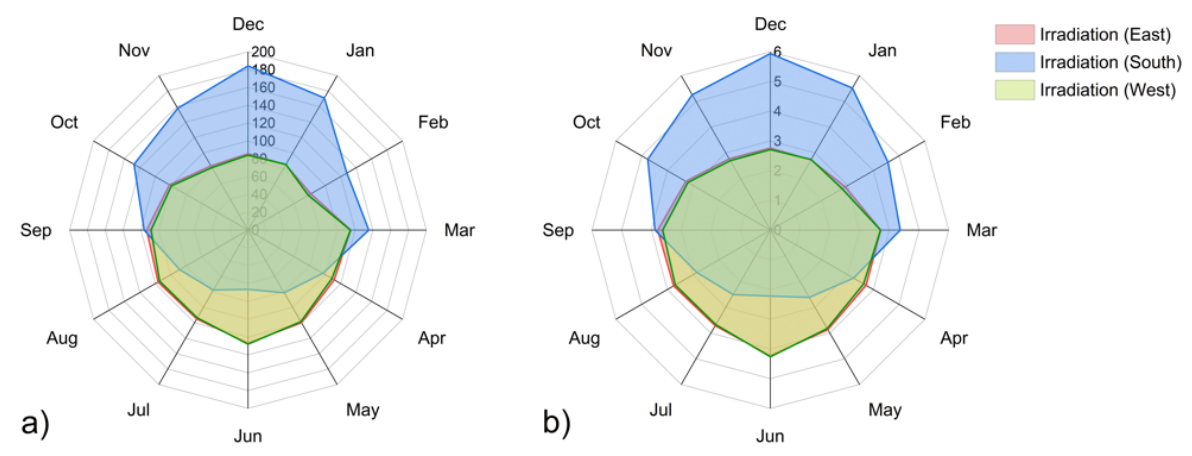

Figure 3: $90^{\circ}$ Plane. Solar irradiation $\left(\mathrm{kWh} / \mathrm{m}^{2}\right)$. (a) Monthly; and (b) Monthly mean daily.

We present the normalized average monthly energy yield for the CIGS and c-Si modules in Fig. 4. The energy production of each façade reflected the variability of the incident solar energy across the year. Furthermore, the energy yield of the c-Si modules was higher than the CIGS modules in all orientations and across all the months of the year. In December, the modules of both technologies reached their maximum production $-19.2 \mathrm{kWh} / \mathrm{m}^{2}$ by the CIGS, and $21.2 \mathrm{kWh} / \mathrm{m}^{2}$ by the $\mathrm{c}-\mathrm{Si}$. The south-oriented modules produced more energy than 


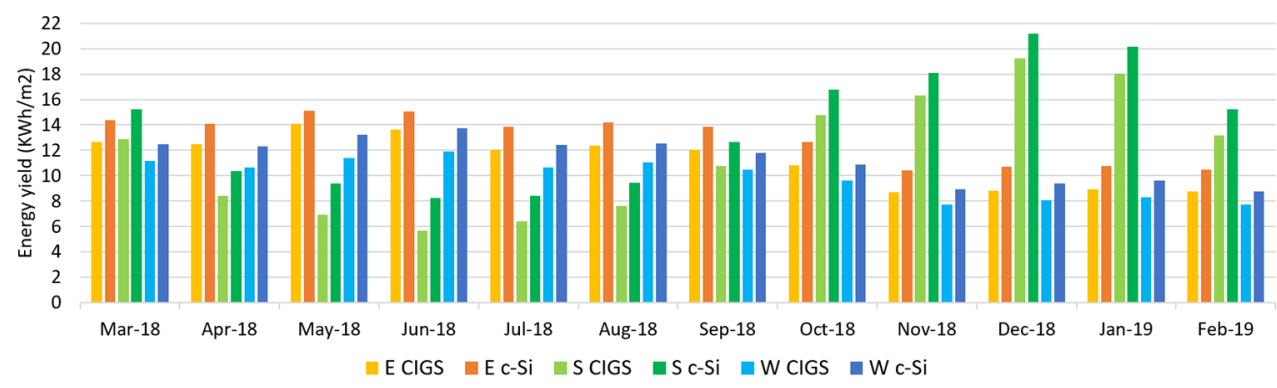

Figure 4: Normalized average monthly energy yield for CIGS and c-Si modules in the east, south and west orientation.

those in the east and west during the period from October to February. In this period, their normalized energy yield was $41.6 \%$ higher than the east modules and $48.5 \%$ higher than the western ones.

The annual normalized energy yields for CIGS and c-Si modules in the east, south, and west orientation (shown in Table 1) are pointing out that the south orientation is the best option for the BIPV ventilated façades, regardless of the technology. However, observing the seasonal variation in the production of the south modules (Fig. 4), we noted that from April to September, which are months with high energy demand in Dubai's buildings, their energy yield was lower than the modules in the east and west. The east and west modules produced between $32.5 \%$ and $40.9 \%$ more energy than the south in the period from April to August. The east façade production was also higher than the south in September. Therefore, the energy contribution of the east and west façades in the hottest months of the year is a feature that the buildings' designers should consider during the design process.

Table 1: Total normalized energy yields.

\begin{tabular}{|l|c|c|c|c|c|c|}
\hline Orientation & \multicolumn{2}{|c|}{ East } & \multicolumn{2}{c|}{ South } & \multicolumn{2}{c|}{ West } \\
\hline Technology & CIGS & c-Si & CIGS & c-Si & CIGS & c-Si \\
\hline $\begin{array}{l}\text { Annual energy yield } \\
\left(\mathrm{kWh} / \mathrm{m}^{2}\right)\end{array}$ & 135.35 & 155.57 & 140.18 & 165.13 & 118.73 & 136.08 \\
\hline Technology relative value & 0.97 & 0.94 & 1.00 & 100 & 0.85 & 0.82 \\
\hline
\end{tabular}

High temperatures reduce the capability of PV modules to produce electricity. To get a better understanding of the working conditions of the integrated PV modules in the harsh climate of Dubai, we analyzed the temperatures of the modules during the whole year. For this analysis, we selected the periods in which the irradiation in each façade was equal to or higher than $300 \mathrm{kWh} / \mathrm{m}^{2}$ and summarized the monthly temperature statistics in Fig. 5.

Although the annual irradiance on the west was only $1.7 \%$ lower than the east, the production of the west modules was at least $12 \%$ less. We found that the different PV modules temperatures have caused the difference in production in these orientations. The average monthly temperatures of the modules at the west were continuously higher than the ones in the east, with the exception of April and May, as can be seen in Fig. 5.

For a better understanding, we analyzed the ambient temperatures and the irradiation in the east and west façades during multiple days from different seasons. The information of 


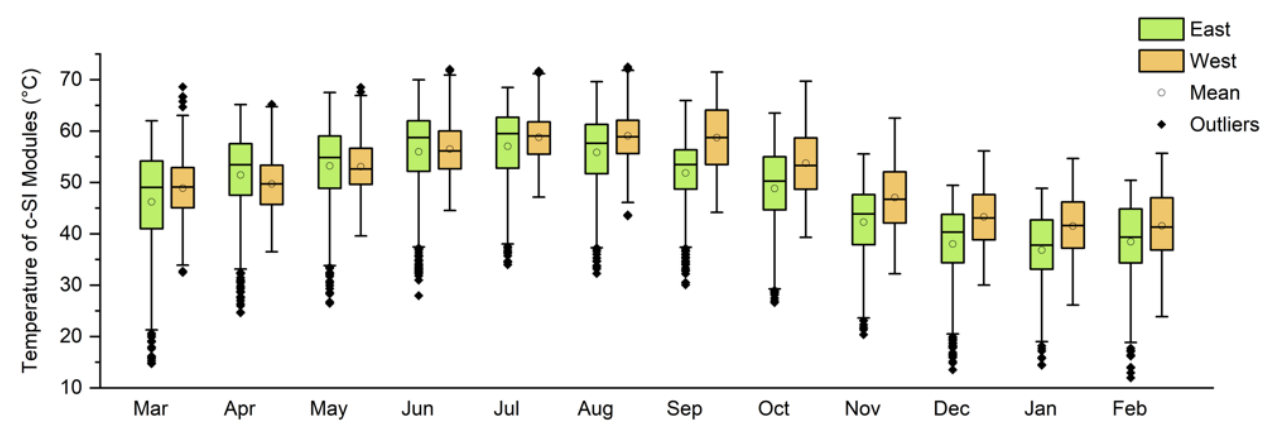

(a)

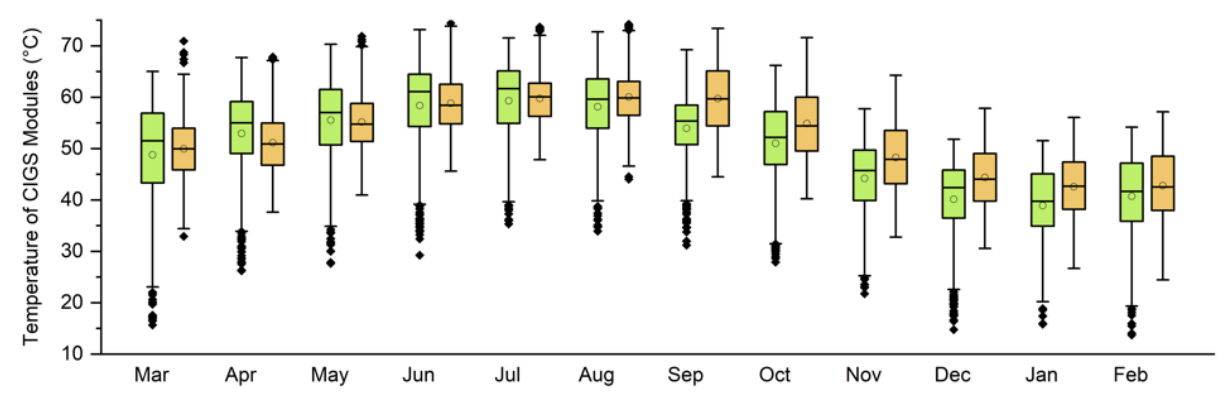

(b)

Figure 5: Monthly temperature ranges of the PV Modules. (a) c-SI modules; and (b) CIGS modules.

29 July and 18 December are presented in Fig. 6. Examining the daily evolution of the temperature and irradiation, we noted that the east modules start to receive high levels of irradiation in the mornings, after being cooled down during the night and when the diurnal temperature is lower, as illustrated in Fig. 6(a) and 6(b). During the afternoons, when the ambient temperature is of higher values, these modules do not receive direct solar irradiation. Similarly, the west modules do not receive direct solar radiation during the mornings, when the diurnal temperature is lower. However, the west panels start to receive direct solar irradiation at noon when the ambient temperature reaches its higher values and after being warmed up during the morning. Although the east modules also reach high temperatures, their temperatures were lower than the ones in the west during their more productive periods.

On 29 July, the east modules received 4\% more irradiation than the west modules. However, the normalized energy yields of the CIGS and c-Si cladding in this orientation were $15 \%$ and $19 \%$ higher respectively. Similarly, on 18 December, the east modules received 5\% more irradiation than the west ones, and their energy yields were $11 \%$ and $21 \%$ higher than the west modules. In the annual and seasonal analysis, the east oriented modules perform better than the ones in the west, for both technologies. Therefore, in cities with climate and latitude similar to Dubai, the second better orientation for BIPV façades is the east, with the south being the first. However, buildings' professionals should not exclude the west orientation in the design consideration; the energy contribution of the BIPV façades facing west coincides with the Dubai peak demand period, which is from 12:00 to 18:00 [1]. 

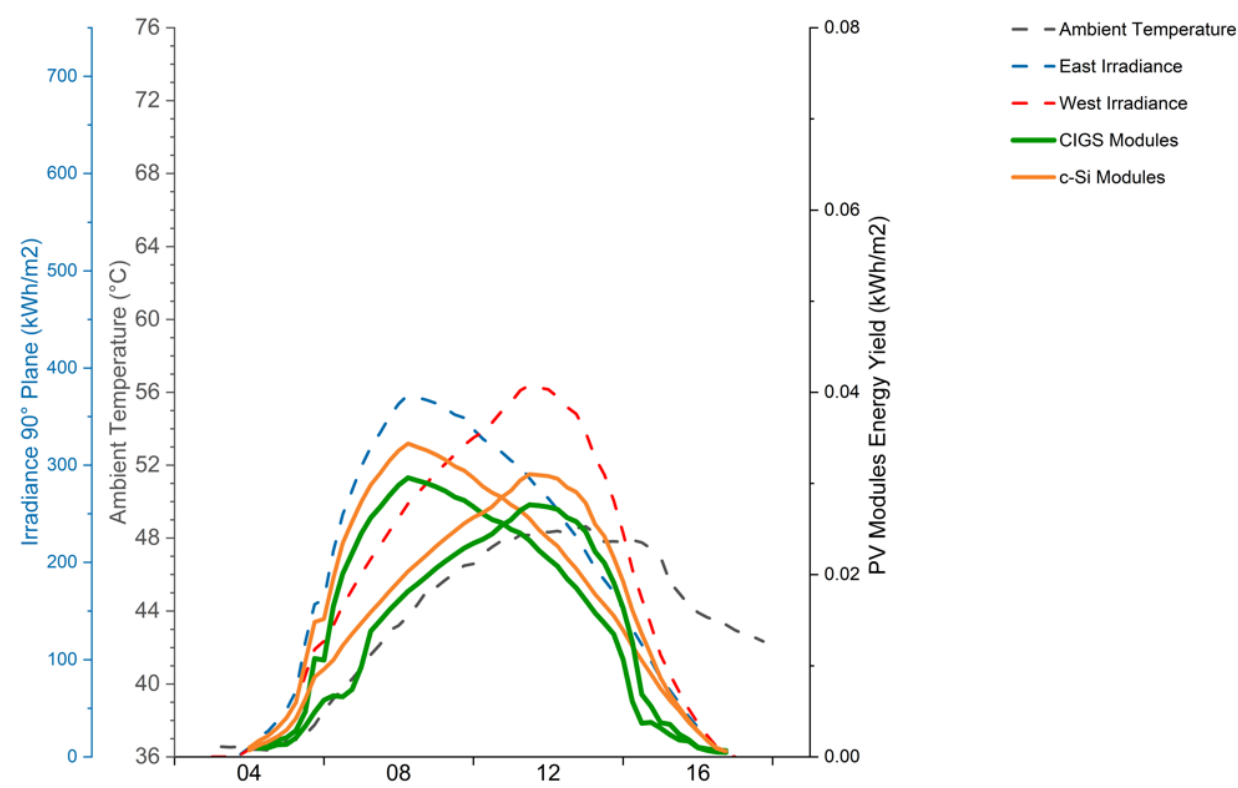

(a)

July 29

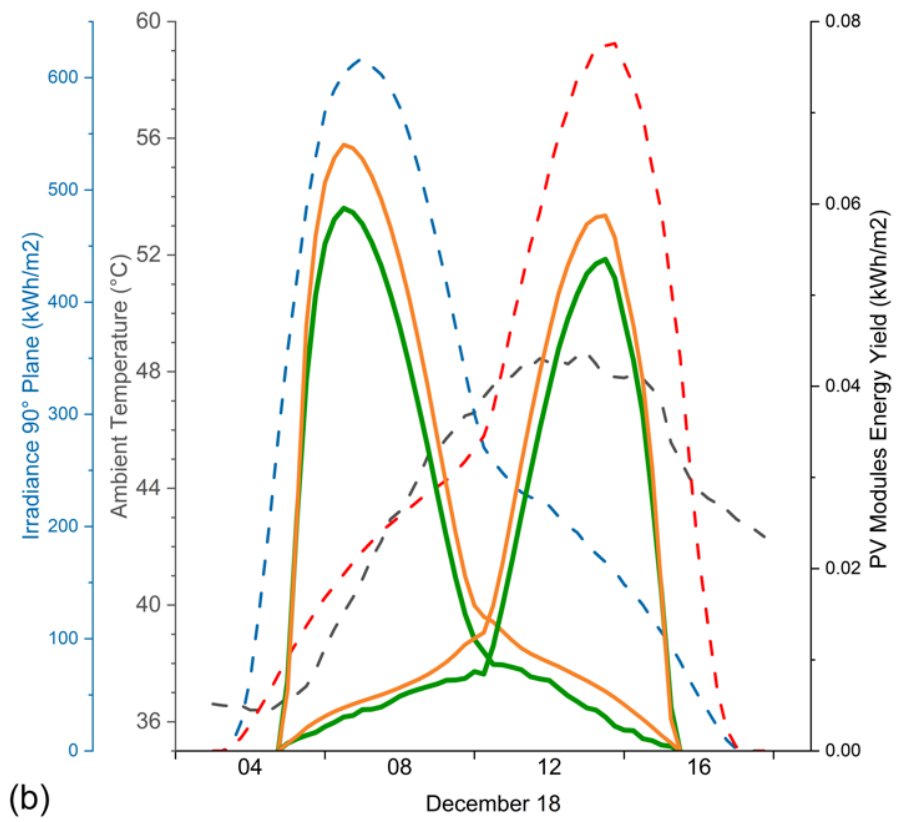

Figure 6: Ambient temperature and $90^{\circ}$. Plane daily irradiation at the east and west. (a) Winter day - 18 December; and (b) Summer day - 29 July. 


\section{CONCLUSION}

This paper presents a test and validation research on the energy performance of BIPV ventilated façades in the desert climate of Dubai. We carried out a 1 year monitoring to assess the performance of copper indium gallium selenide (CIGS) and monocrystalline silicon (c-Si) modules in the three most suitable orientations for Dubai's buildings (south, east and west). Additionally, we investigated the effect of the high temperatures on the modules' energy yield.

The c-Si modules had a higher normalized energy yield during all months and in all orientations. When we compared the annual production, we found that the c-Si modules produced $17 \%$ more energy than the CIGS in the south façade, and $15 \%$ more in the east and west.

Irrespective of the technology, the annual energy production of the south oriented BIPV modules was higher than the east and west modules. As in other Northern Hemisphere cities, the south is the optimal orientation for BIPV façades. However, the east and west façades produced up to $40.9 \%$ more energy than the south in the period from April to August, which are months with high energy demand. The buildings' designers must consider these other orientations if they wish to increase the energy production during these months, or if there is some limitation on the use of the south façade.

Although the annual irradiance on the west was only $1.7 \%$ lower than the east, the production of the west modules at least $12 \%$ less, due to the effect of the afternoon high temperatures. Therefore, in cities with climate and latitude similar to Dubai, the second better orientation for BIPV façades is the east. However, building professionals should not discard the west orientation until considering its potential benefit on the daily peak demand.

In our future research works, we will investigate the impact of the rear ventilation (rate and temperature) on the energy production of the CIGS and c-Si modules integrated on ventilated façades, and the influence of this type of BIPV façades on the buildings' cooling energy consumption in arid climates.

\section{ACKNOWLEDGEMENTS}

The authors would like to acknowledge Dubai Electricity and Water Authority (DEWA) for funding this research, Dr. Sgouris Sgourdis, Director of Research from DEWA R\&D, for his valuable inputs, and Dr. Jim John, Ahmad Safieh, Ammar Elnosh and Omar Albadwawi, members of the DEWA R\&D Solar Area, for their support.

\section{REFERENCES}

[1] TAQATI, 2018 Annual Report: Dubai Demand Side Management Strategy, 2018.

[2] Ferrara, C., Wilson, H.R. \& Sprenger, W., Building-Integrated Photovoltaics (BIPV), in the Performance of Photovoltaic (PV) Systems: Modelling, Measurement and Assessment, 2017.

[3] Ogden, T. \& Uslu, T., Electrifying the Walls: Growing Competition in BuildingIntegrated Photovoltaics, 2016.

[4] Agathokleous, R.A. \& Kalogirou, S.A., Status, barriers and perspectives of building integrated photovoltaic systems. Energy, 191, p. 116471, 2020.

DOI: $10.1016 /$ j.energy.2019.116471.

[5] Elnosh, A. et al., Field study of factors influencing performance of PV modules in buildings (BIPV/BAPV) installed in UAE. 2018 IEEE 7th World Conference Photovoltaic Energy Conversion, WCPEC 2018: A Joint Conference, 45th IEEE PVSC, 28th PVSEC 34th EU PVSEC, pp. 565-568, 2018.

DOI: 10.1109/PVSC.2018.8547298. 
[6] Asghar A. \& Emziane, M., BIPV applications in the GCC region: A comparative study on the key parameters. Smart Innov. Syst. Technol., 12, pp. 609-617, 2012.

DOI: 10.1007/978-3-642-27509-8_51.

[7] Radhi, H., On the value of decentralised PV systems for the GCC residential sector. Energy Policy, 2011. DOI: 10.1016/j.enpol.2011.01.038.

[8] Mokri, A., Aal Ali, M. \& Emziane, M., Solar energy in the United Arab Emirates: A review. Renew. Sustain. Energy Rev., 28, pp. 340-375, 2013. DOI: 10.1016/j.rser.2013.07.038.

[9] Van Beuzekom, I., Hodge, B.M. \& Slootweg, H., Projecting solar photovoltaic efficiencies from lab to market. 2018 IEEE International Energy Conference, ENERGYCON 2018, 2018. DOI: 10.1109/ENERGYCON.2018.8398813.

[10] Alim, M.A. et al., Is it time to embrace building integrated Photovoltaics? A review with particular focus on Australia. Sol. Energy, 188, pp. 1118-1133, 2019. DOI: 10.1016/j.solener.2019.07.002.

[11] Mubarak, R., Luiz, E.W. \& Seckmeyer, G., Why PV modules should preferably no longer be oriented to the south in the near future. Energies, 2019.

DOI: $10.3390 /$ en 12234528 .

[12] Stoichkov, V., Sweet, T.K.N., Jenkins, N. \& Kettle, J., Studying the outdoor performance of organic building-integrated photovoltaics laminated to the cladding of a building prototype. Sol. Energy Mater. Sol. Cells, 191, pp. 356-364, 2019.

DOI: 10.1016/j.solmat.2018.11.040.

[13] Martín-Chivelet, N., Gutiérrez, J.C., Alonso-Abella, M., Chenlo, F. \& Cuenca, J., Building retrofit with photovoltaics: Construction and performance of a BIPV ventilated façade. Energies, 11(7), 2018. DOI: 10.3390/en11071719.

[14] Shahrestani, M. et al., Experimental and numerical studies to assess the energy performance of naturally ventilated PV façade systems. Sol. Energy, 147, pp. 37-51, 2017. DOI: 10.1016/j.solener.2017.02.034.

[15] Agathokleous, R.A. \& Kalogirou, S.A., Double skin façades (DSF) and building integrated photovoltaics (BIPV): A review of configurations and heat transfer characteristics. Renew. Energy, 89, pp. 743-756, 2016.

DOI: $10.1016 /$ j.renene.2015.12.043.

[16] Agathokleous, R.A. \& Kalogirou, S.A., Part II: Thermal analysis of naturally ventilated BIPV system: Modeling and simulation. Sol. Energy, 169, pp. 682-691, 2018. DOI: 10.1016/j.solener.2018.02.057.

[17] Sanjuan, C., Suárez, M.J., González, M., Pistono, J. \& Blanco, E., Energy performance of an open-joint ventilated façade compared with a conventional sealed cavity façade. Sol. Energy, 85(9), pp. 1851-1863, 2011. DOI: 10.1016/j.solener.2011.04.028. 